\title{
PEMANFAATAN LIMBAH TRIPLEK UNTUK PERANCANGAN MOBIL MAINAN ANAK YANG ERGONOMIS
}

\author{
Nur Wahidah ${ }^{1)}$, Trismawati $^{2)}$, Haryono ${ }^{3)}$ \\ 1,2,3 Jurusan Teknik Industri, Universitas Panca Marga,Jl. Yos Sudarso, Probolinggo 67271, Indonesia \\ E-mail : brianhery22@gmail.com
}

\begin{abstract}
Abstrak, Salah satu kekurangan dari suatu produk mobil mainan anak adalah kurang ergonomis atau ukuran yang tidak sesuai umur tubuh anak dan mahalnya harga mobil mainan anak yang dijual di pasar. Penelitian ini untuk melakukan suatu perancangan dan pengembangan mobil mainan anak dengan memanfaatkan limbah triplek. Penulis menggunakaan metode antropometri dalam perancangann. Untuk pengembangan memanfaatkan hanphone android untuk remote mobil mainan anak. Berdasarkan keinginan konsumen timbul gagasan pengembangan dan pemanfaatan limbah untuk seleksi konsep yang ada. Konsep yang terpilih yaitu produk satu yang sesuai dengan keinginan konsumen. Maka dapat diusulkan memanfaatkan bahan triplek yang tidak terpakai di pabrik untuk membuat mobil mainan anak yang ergonomis pada anak-anak TK (Taman kanak-kanak)
\end{abstract}

Kata Kunci : Perancangan, Ergonomis, Mobil mainan anak, Limbah triplek

\section{PENDAHULUAN}

Mobil mainan yang dipasaran terbuat dari bahan plastik yang sudah banyak di pasarkan. Mobil mainan telah membutuhkan keterampilan,memang umumnya anak-anak yang sudah memainkan mobil mainan maka akan memiliki banyak manfaat untuk perkembangan anak(Meilani, 2016). Seperti kita tahu anak-anak belajar tentang dunianya dengan mencontoh orang dewasa. Keterampilan utama pada mobil mainan adalah keamanan dan kenyamanan.

Mainan yang menyerupai mobil dan juga berarti tiruan mobil. Mobil-mobilan memiliki banyak manfaat untuk perkembangan. Seperti yang kita ketahui anak-anak belajar tentang dunia mereka dengan meniru orang dewasa di sekitar mereka dan melalui bermain. Itulah sebabnya sesi perkembangan dan perkembangan anak menggunakan banyak waktu untuk bermain sebagai alat observasi.

Maka Mobil Mainan manfaatakan limbah triplek yang tidak terpakai di pabrik maka untuk dimanfaatkan menjadi mobil mainan anak yang ergonomis. Maka mobil mainan anak membutuhkan pengukuran Metode antropometri pada anak-anak di TK (Taman kanak-kanak) agar mobil mainan anak menjadi ergonomis dan nyaman di pakai oleh anak-anak.

\section{DASAR TEORI \\ Ergonomi}

Istilah "ergonomi" berasal dari bahasa Latin yaitu ERGO (pekerjaan) dan NONOS (hukum alam) dan dapat didefinisikan sebagai studi tentang aspek manusia dalam lingkungan kerja yang ditinjau secara anotomik, psikologis, fisiologis, teknik, manajemen dan rancangan. Ergonomi juga berkaitan dengan optimalisasi, efisiensi, kesehatan, keselamatan dan kenyamanan manusia di tempat kerja, rumah, dan pengaturan rekreasi (Andriani, M \& Subhan, 2016). Ergonomi adalah cabang ilmu yang sistematis untuk memanfaatkan informasi tentang sifat, kemampuan dan keterbatasan manusia untuk merancang sistem kerja sehingga orang dapat bekerja dengan baik, yaitu mencapai tujuan yang diinginkan melalui pekerjaan, secara efektif, secara publik dan nyaman (R. Siregar, L. N. Huda, A. J. M. Rambe 2014).

Ergonomi adalah aplikasi sistematis pengetahuan yang dipilih tentang manusia dan desain sistem objek manusia, fasilitas manusia dan lingkungan manusia. Dengan kata lain , ergonomi adalah ilmu yang mempelajari manusia untuk berinteraksi dengan benda-benda fisik dalam berbagai kegiatan sehari-hari (Nurmianto, E. 2004). Salah satu pendekatan yang dapat digunakan untuk merancang mobil mainan yang lebih ergonomis dilakukan dengan 
pendekatan antropometrik. Dengan pendekatan antropometrik ini kita bisa mendapatkan desain mobil mainan yang lebih ergonomis yang disesuaikan dengan ukuran tubuh anak-anak, sehingga diperoleh dimensi mainan anak yang sesuai.

\section{Antropometri}

Kata antropometri berasal dari bahasa Yunani (Greek), yang merupakan antropos yang berarti manusia (manusia, manusia) dan meterrein (untuk mengukur) yang berarti ukuran.Antropometri adalah bidang ilmu yang berhubungan dengan dimensi tubuh manusia (Wignjosoebroto, 2008). Dimensi ini dibagi ke dalam statistik dan persentil ke-14.Jika seratus orang berdiri dalam barisan dari yang terkecil hingga yang terbesar secara berurutan, ini dapat diklasifikasikan dari 1 persen menjadi 100 persen. Data dimensi manusia ini sangat berguna dalam desain produk dengan tujuan menemukan kompatibilitas produk dengan orang-orang yang menggunakannya. Penggunaan data antropometrik membuat semua alat disesuaikan dengan kemampuan manusia, bukan manusia disesuaikan dengan alat. Desain yang menggunakannya sangat penting untuk mengurangi munculnya bahaya karena kesalahan kerja karena kesalahan desain (desain-induced error) (Trismawati, 2018). Dengan demikian antropometri berguna untuk menyesuaikan desain alat dengan manusia yang menggunakannya sehingga tidak ada bahaya kesalahan pekerjaan karena tidak sesuai dengan pengguna alat.

Antropometri adalah bidang ilmu yang berhubungan dengan dimensi tubuh manusia. Di dunia industri, pendekatan antropometri diperlukan, misalnya dalam desain alat dan peralatan. Tujuan dari pendekatan Antropometri dalam perancangan alat dan peralatan adalah untuk menciptakan harmoni antara manusia dan sistem kerja (sistem manusia-mesin), sehingga tenaga kerja dapat bekerja dengan nyaman, baik, dan efisien. Pentingnya memperhatikan factor ergonomi dalam proses rancang bangun fasilitas saat ini adalah merupakan sesuatu yang tidak dapat ditunda lagi hal tersebut tidak akan akan terlepas dari perbuatan dari pembahasan penerapan data - data antropometri (Eko Nurmianto, 2004).

\section{METODE PENELITIAN}

Langkah dalam penelitian ini dapat dilihat di Gambar 1. Tahap pertama adalah melalukan pengumpulan data. Data yang dikumpulkan merupakan data antropometri anak Taman kanak-kanak RAHDATUL HASAN sebanyak 20 anak. Data antropometri yang dikumpulkan selanjutnya diolah dengan melakukan pengujian statistik meliputi: pengujian kenormalan data, pengujian keseragaman data, pengujian kecukupan data. Kemudian dengan memperhatikan konsep perancangan produk dilakukan perancangan mobil mainan anak dengan menyesuaikan dengan data antropometri yang digunakan. Langkah terahir adalah melakukan analisis terhadap hasil rancangan, dimana pada tahap ini dilakukan pembandingan antara mobil mainan anak yang di rancang dengan mobil mainan anak yang sudah ada.

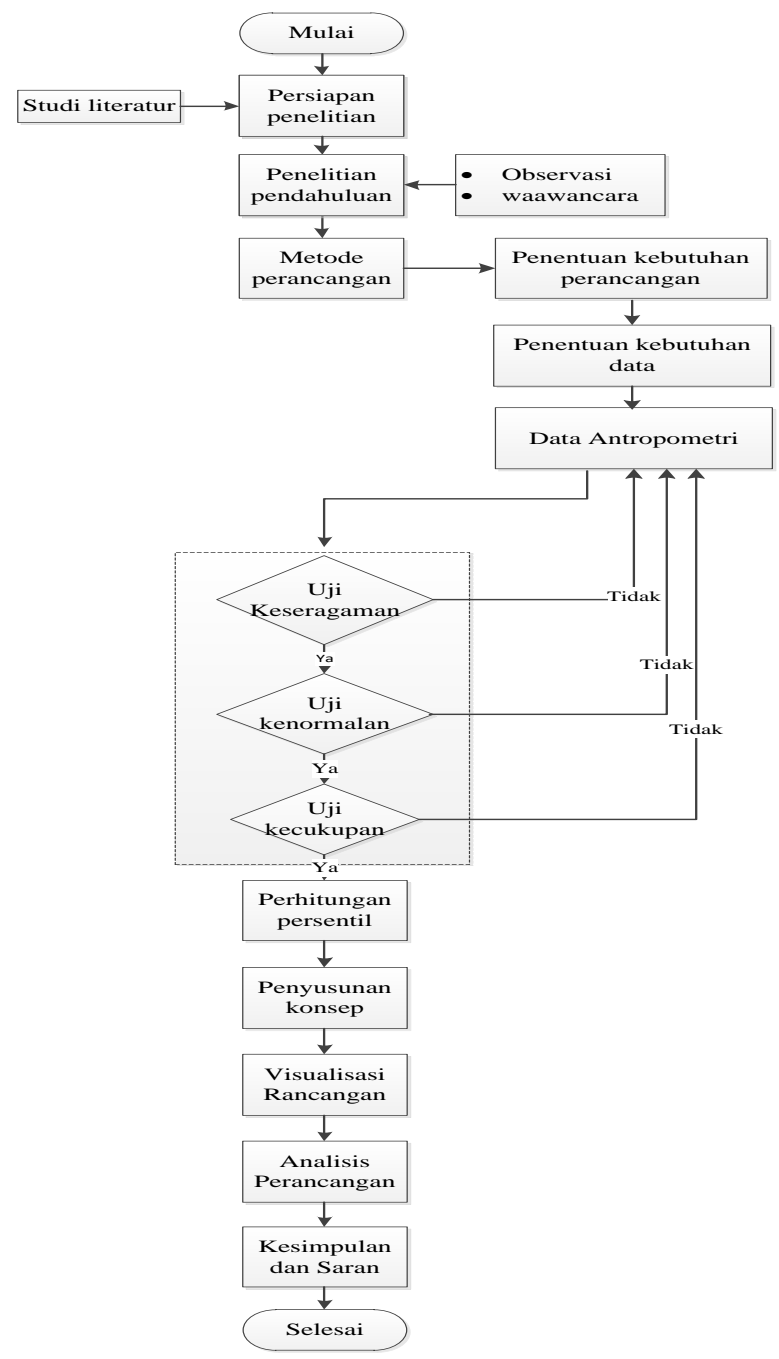

Gambar 1. Kerangka penelitian 


\section{HASIL DAN PEMBAHASAN \\ Pengumpulan Data}

Data yag digunakan merupakan data antropometri anak taman kanak-kanak RAHDATUL HASAN. Adapun data Antropometri yang diperlukan adalah:

1. Lebar pinggul

2. Tinggi siku duduk

3. Lebar bahu

4. Lebar tangan

5. Tinggi lutut duduk

6. Tinggi jangkuan tangan tegak

7. Tinggi badan tegak

8. Pantat ke lutut

9. Tinggi sandaran punggung

\section{Uji Kenormalan Data}

Uji kenormalan data dapat dilihat pada Tabel 1. Tabel 1 dapat digunakan untuk melihat apakah data yang diperoleh merupakan data yang berdistribusikan normal atau tidak. Untuk uji kenormalan ini digunakan hipotesis.

Tabel 1. Rekapitulasi hasil uji kenormalan data pinggul anak yang paling kecil sebesar $25 \mathrm{~cm}$ dan yang paling besar $30 \mathrm{~cm}$.

Untuk Gambar 3 grafik lebar pinggul dapat dilihat bahwa data antropometri dari 20 anak untuk ukuran lebar pinggul tidak melebihi batas kontrol atas atau batas kontrol bawah data dikatakan seragam.

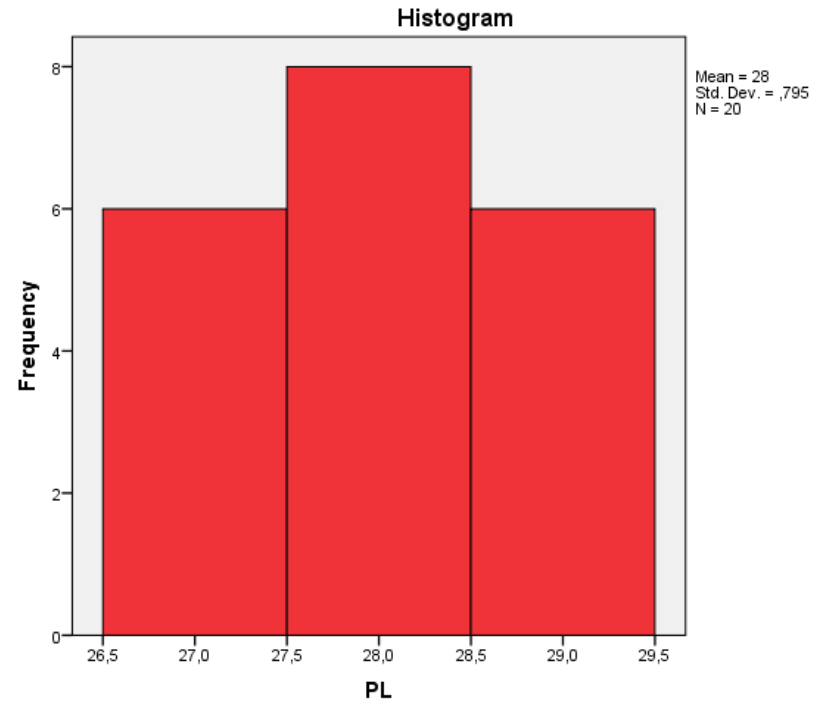

Gambar 2. Grafik uji kenormalan data untuk lebar pinggul

\begin{tabular}{|l|l|l|l|l|l|}
\hline \multirow{2}{*}{} & \multicolumn{3}{|l|}{ Kolmogorov-Smirnov $^{\mathrm{a}}$} & \multicolumn{2}{l|}{ Shapiro-Wilk } \\
\cline { 2 - 6 } & Statistic & Df & Sig. & Statistic & df \\
\hline PL &, 200 & 20 &, 035 &, 813 & 20 \\
TSD &, 255 & 20 &, 001 &, 787 & 20 \\
LB &, 200 & 20 &, 035 &, 813 & 20 \\
LT &, 200 & 20 &, 035 &, 813 & 20 \\
TLD &, 225 & 20 &, 009 &, 803 & 20 \\
TJTT &, 280 & 20 &, 000 &, 784 & 20 \\
TBT &, 211 & 20 &, 020 &, 853 & 20 \\
PKL &, 287 & 20 &, 000 &, 776 & 20 \\
TSP &, 326 & 20 &, 000 &, 751 & 20 \\
\hline
\end{tabular}

\section{Uji keseragaman data}

Uji keseragaman data digunakan untuk melihat apakah data yang di peroleh merupakan data yang seragam atau tidak.

Dari hasil uji keeragaman data, didapatkan data seragam untuk semua item data antropometri yang telah dikumpulkan. Grafik uji keseragaman untuk lebar pinggul dapat dilihat pada Gambar 2. Pada Gambar 2 berdasarkan data histogram menunjukkan bahwa data lebar

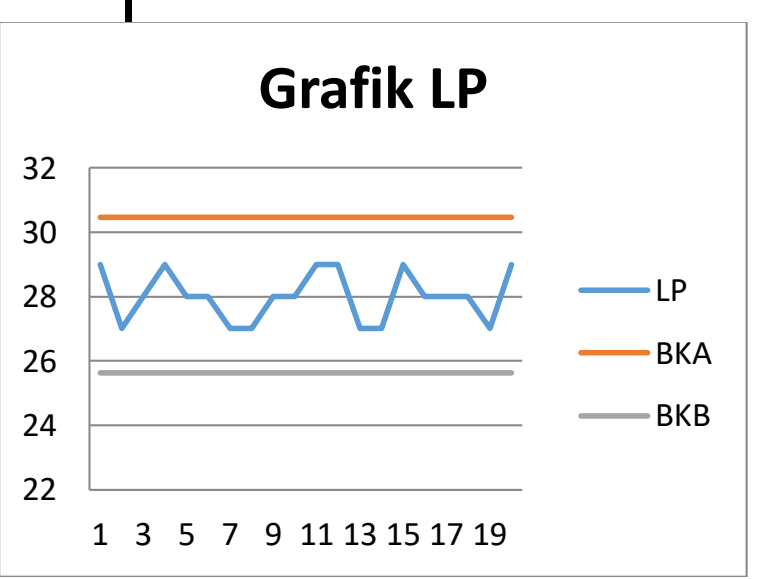

Gambar 3. Grafik keseragaman data lebar pinggul

\section{Uji kecukupan data}

Uji kecukupan data dilakukan untuk melihat apakah data penelitian telah cukup jumlahnya atau tidak. Untuk Tabel 2 hasil kecukupan data yang sudah terhitung dari tinggi dada sampai tinggi sandaran punggung. 
Tabel 2. Hasil kecukupan data

\begin{tabular}{|l|l|l|}
\hline Data pengukuran & $\mathrm{N}$ & $\mathrm{N}^{\prime}<\mathrm{N}$ \\
\hline Tinggi dada & 20 & 1.21 \\
\hline Tinggi siku dada & 20 & 2.49 \\
\hline Lebar bahu & 20 & 2.62 \\
\hline Lebar tangan & 20 & 0.56 \\
\hline $\begin{array}{l}\text { Tinggi lutut } \\
\text { duduk }\end{array}$ & 20 & 1.06 \\
\hline $\begin{array}{l}\text { Tinggi jangkuan } \\
\text { tangan tegak }\end{array}$ & 20 & 0.43 \\
\hline $\begin{array}{l}\text { Tinggi tangan } \\
\text { tegak 20 }\end{array}$ & 648.25 \\
\hline Pantat ke lutut & 20 & 70.25 \\
\hline $\begin{array}{l}\text { Tinggi sandaran } \\
\text { punggung }\end{array}$ & 20 & 14.88 \\
\hline
\end{tabular}

Dari hasil pengolahan data dengan menggunakan tingkat keyakinan $95 \%$ dan tingkat ketelitian 5\%, diperoleh semua data yang dikumpulakan telah cukup karena nilai data yang diperlukan $\left(\mathrm{N}^{\prime}\right)<$ data yang dikumpulkan $(\mathrm{N})$.

\section{Penentuan Persentil}

Besarnya nilai persentil dapat ditentukan dari tabel probabilitas distribusi normal. Persentil adalah batas rentang yang dapat dipakai. Pada Tabel 3 hasil pengukuran perhitungan persentil data antropometri dari lebar pinggul sampai tinggi sandaran punggung.

Tabel 3. Rekapitas hasil perhitungan persentil

\begin{tabular}{|l|l|l|l|}
\hline No & Dimensi & $\begin{array}{l}\text { Persentil } \\
(\mathrm{cm})\end{array}$ & $\begin{array}{l}\text { Ukuran } \\
(\mathrm{cm})\end{array}$ \\
\hline 1 & $\begin{array}{l}\text { Lebar } \\
\text { Pinggul }\end{array}$ & 28.17 & 28 \\
\hline 2 & $\begin{array}{l}\text { Tinggi } \\
\text { siku } \\
\text { duduk }\end{array}$ & 21.09 & 21 \\
\hline 3 & $\begin{array}{l}\text { Lebar } \\
\text { bahu }\end{array}$ & 19.17 & 19 \\
\hline 4 & $\begin{array}{l}\text { Lebar } \\
\text { tangan }\end{array}$ & 41.17 & 41 \\
\hline 5 & $\begin{array}{l}\text { Tinggi } \\
\text { lutut } \\
\text { duduk }\end{array}$ & 31.08 & 31 \\
\hline 6 & $\begin{array}{l}\text { Tinggi } \\
\text { jangkuan } \\
\text { tangan } \\
\text { tegak }\end{array}$ & 45.94 & 46 \\
\hline
\end{tabular}

\begin{tabular}{|l|l|l|l|}
\hline 7 & $\begin{array}{l}\text { Tinggi } \\
\text { badan } \\
\text { tegak }\end{array}$ & 106.66 & 107 \\
\hline 8 & $\begin{array}{l}\text { Pantat ke } \\
\text { lutut }\end{array}$ & 33.67 & 34 \\
\hline 9 & $\begin{array}{l}\text { Tinggi } \\
\text { sandaran } \\
\text { punggung }\end{array}$ & 33.29 & 33 \\
\hline
\end{tabular}

Sumber: Data diolah oleh penulis

\section{Analisis mobil mainan anak}

Pada perancangan mobil mainan anak dilakukan analisis diferensasi untuk mengetahui kelebihan dan kekurangan produk pembanding. Hasil analisis diferensasi pada produk mobil mainan anak tersebut dapat dijadikan sebagai pertimbangan dalm perancangan. Adapun analisis diferenssi difokuskan pada keamanan dan kenyaman pada anak-anak. Adapun aspek perancangan mobil mainan anak yaitu aspek pengguna, aspek ergonomi , aspek antropometri. Dan menfaatkan limbah limbah triplek untuk di jadikan mobil mainan anak dapat meningkatkan nilai tambah UD.345gerongan kecamatan maron karena limbah triplek selama ini dibiarkan di tumpuk pencemaran lingkungan dan penyempitkan area kerja.dalam pemanfaatan limbah triplek menjadi produk yang bermanfaatkan bagi anak-anak.

\section{Hasil desain gambar mobil mainan anak}

- Gambar sketsa mobil mainan anak dari limbah triplek :

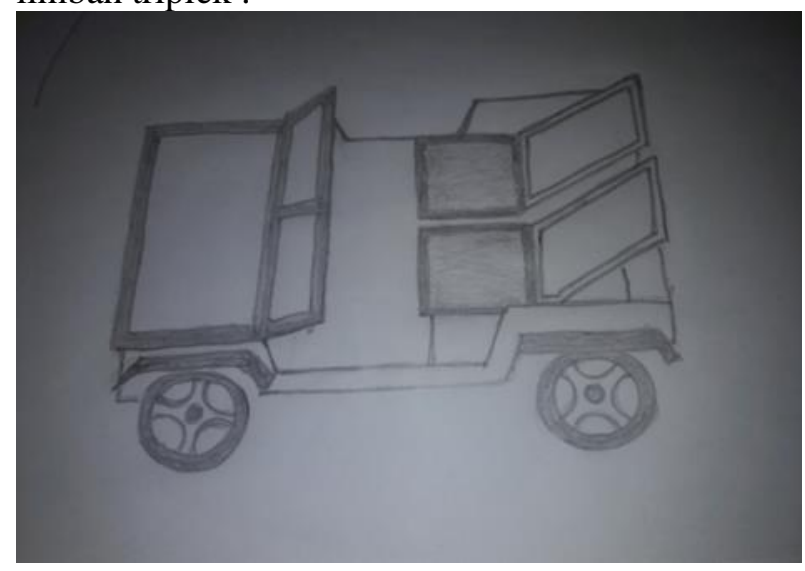

\section{KESIMPULAN}

Berdasarkan uraian yang telah dijelaskan sebelumnya, dapat disimpulkan beberapa hal diantaranya:

1. Sampah di UD.345gerongan Ada banyak yang tidak dimanfaatkan dengan baik, 
menyebabkan berbagai

masalah.Olehkarenaitudiperlukan ide untukmemanfaatkanlimbah triplek untuk menjadi produk mobil mainan anak yang ergonomis.

2. untuk pengembangan mobil mainan anak dengan memanfaatkan smart phone android untuk remote atau mengukur jarak jauh mobil mainan anak.

\section{DAFTAR PUSTAKA}

Andrianto, Efendi., Trismawati, Trismawati., Suhandini, Yustina. 2018. "Perancangan Produk APE dengan Menggunakan Metode Quality Function Deployment (QFD).

Andriani, M \& Subhan, 2016 Perancangan Peralatan Secara Ergonomi Untuk Meminimalkan Kelelahan Di Pabrik Kerupuk
Meilani, 2016. "Hubungan Antara Aktivitas Bermain Pembangunan dengan Kemampuan Motorik Halus Usia 5-6 Tahun di TK I Istiqlal Rajabasa Bandar Lampung, Jurnal Penelitian PAUDIA, Vol. 1, No. 1.

R. Siregar, L. N. Huda, A. J. M. Rambe. (2014, Juli). Perancangan Kursi dan Meja Berdasarkan Antropometri Pada Sekolah Dasar Swasta X. Jurnal Tenik Industri.

Nurmianto, E. 2004. "Analisa Hasil Pengukuran Kelelahan Tahun 2011 Berdasar Data Overtime, Absensi Sakit dan Produktivitas Kerja pada Tahun 2010 pada Tenaga Kerja Produksi PT. Dupont Agricultural Produt Indonesia Surabaya Plant”. Semarang : Universitas Sebelas Maret.

Widodo, I., "Perencanaan dan Pengembangan Produk", UII Press, Jogyakarta. 2005.

Wignjosoebroto, 2008. "Ergonomi Studi Gerak dan Waktu, Surabaya : Guna Widya. 